Małgorzata Grzonka*

Uniwersytet Śląski w Katowicach

(D) https://orcid.org/0000-0003-2251-9375

Katarzyna Romaniuk**

Uniwersytet Śląski w Katowicach

(D) https://orcid.org/0000-0001-5204-1283

DOI: http://doi.org/10.31261/FL.2019.06.19

\title{
Sprawozdanie z konferencji naukowej „Zaburzenia płynności mowy - teoria i praktyka. Edycja III" (Katowice, 31 sierpnia - 1 września 2018)
}

\author{
A Report from the Academic Conference \\ "Speech Disorders - Theory and Practice. Third Edition" \\ (Katowice, 31 August - 1 September 2018)
}

Międzynarodowa Konferencja Logopedyczna „Zaburzenia płynności mowy - teoria i praktyka. Edycja III" odbyła się w dniach 31 sierpnia - 1 września 2018 roku na Wydziale Teologicznym Uniwersytetu Śląskiego w Katowicach. Jej organizatorzy to: Fundacja Wiedzy i Dialogu Społecznego „Agere Aude”, Instytut Języka Polskiego im. Ireny Bajerowej Uniwersytetu Śląskiego w Katowicach oraz Wydział Teologiczny tegoż Uniwersytetu.

Tematyka konferencji obejmowała zagadnienia niezwykle ważne dla społeczności naukowej, zwłaszcza logopedycznej i językoznawczej, bo dotyczące szeroko pojmowanej komunikacji, zaburzeń płynności mowy, terapii jąkania się, giełkotu, praktyki logopedycznej, nauczycielskiej i rodzicielskiej związanej z jąkaniem się dzieci i młodzieży. Przedmiotem oglądu uczyniono i teorię, i praktykę logopedyczną.

W III już edycji Międzynarodowej Konferencji Logopedycznej wzięli udział specjaliści $w$ dziedzinie logopedii, reprezentujący zarówno krajowe, jak i zagraniczne ośrodki naukowo-badawcze, oraz przedstawiciele środowisk osób zmagających się z zaburzeniami płynności mowy. Prelegentami byli logopedzi, terapeuci, badacze i nauczyciele akademiccy z różnych ośrodków w Polsce, a także z Belgii, Holandii, Izraela, Malty, Niemiec, Czech, Włoch, Libanu, USA oraz Wielkiej Brytanii. Podczas obu dni konferencji uczestnicy mieli okazję wysłuchać ośmiu tłumaczonych symultanicznie wykładów mistrzowskich (wygłaszanych w czterech częściach), po których mogli udać się na wybrane obrady panelowe, miniseminaria, warsztaty, sesje posterowe i otwarty panel dyskusyjny. Sesje warsztatowe, prowadzone przez wybitnych specjalistów z Malty oraz Wielkiej Brytanii: Josepha Agiusa i Trudy Stewart, tłumaczono konsekutywnie na język polski.

Konferencję otworzyła Ewa Biłas-Pleszak, która po przywitaniu przybyłych uczestników - słuchaczy, prelegentów oraz zaproszonych gości - zapoznała wszystkich z tematyką III edycji wydarzenia. Następnie głos zabrali: Magdalena Pastuch, prodziekan Wydziału Filologicznego ds. promocji i współpracy z otoczeniem, oraz Marek Wójtowicz, prodziekan Wydziału Teologicznego ds. studentów.

\footnotetext{
* e-mail: m.grzonka@onet.pl

** e-mail: romaniukkasia25@gmail.com
} 
Pierwszą część konferencji rozpoczął Tomasz Woźniak, przedstawiciel Uniwersytetu Marii Curie-Skłodowskiej w Lublinie, wygłaszając wykład mistrzowski dotyczący stanu badań i praktyki logopedycznej na początku XXI wieku w zakresie zaburzeń płynności mowy. Jako drugi wystąpił Joseph Agius z Uniwersytetu Maltańskiego - jeden z twórców Europejskiej Klinicznej Specjalizacji Zaburzeń Płynności Mowy (ECSF) - odnosząc się do roli, jaką w terapii jąkania się odgrywa humor. Po dyskusji i krótkiej przerwie uczestnicy konferencji mieli okazję wziąć udział w sesjach panelowych, w których skład wchodziły referaty, miniseminaria oraz warsztaty. Podczas tej części spotkania odczyty wygłosili: Aleksandra Jastrzębowska-Jasińska ("Coaching” kluczem do motywacji w terapii jąkania u osób dorosłych), Maria Faściszewska (Test Rozwoju Językowego (TRJ) w diagnostyce logopedycznej dzieci jąkających się $w$ wieku przedszkolnym i wczesnym), Łukasz Kowalczyk (Praktyki rodzicielskie (zachowania, postawy, style wychowania i przywiazania) a jąkanie się dzieci. Wstępne wyniki badań), Magdalena Ławecka i Natalia Moćko (Wpływ stymulacji słuchowej $w$ kontekście lewouszności na poprawę płynności mowy - studia przypadków). Sesje panelowe obejmowały także miniseminaria prowadzone w języku polskim przez Aleksandrę Boroń (Możliwości i ograniczenia terapii jąkania u dzieci prowadzonej na odległość z wykorzystaniem Internetu), Krzysztofa Szamburskiego i Agnieszkę Siwińską (Metoda wystukiwania sylab jako skuteczny sposób upłynniania mówienia w jąkaniu), oraz w języku angielskim (bez tłumaczenia) - przez Selmę Saad Merouwe ("Szycie” terapii na miarę potrzeb osoby jąkającej się) i Francescę Del Gado (MIDA - Program terapii jąkania: wielowymiarowe, zintegrowane podejście do jakania przy wykorzystaniu sztuki). Ostatnim elementem wchodzącym w skład sesji panelowych były tłumaczone konsekutywnie na język polski warsztaty na temat wykorzystania humoru i kreatywności $w$ terapii jąkania się prowadzone przez Josepha Agiusa.

Po krótkiej przerwie obiadowej rozpoczęła się kolejna część konferencji - sesja posterowa. Uczestnicy mieli możliwość porozmawiania z twórcami plakatów naukowych o zagadnieniach związanych z kwestiami logopedycznymi, które dotyczyły między innymi terapii giełkotu (Terapia jąkania z cechami giełkotu oraz powiązanych zaburzeń u dziecka we wczesnym wieku szkolnym, autorka: Aleksandra Boroń; Studium przypadku młodej osoby z giełkotem i jakaniem, autorki: Danuta Kusz-Marondel, Katarzyna Ploch), bilingwizmu i/lub trójjęzyczności (Stosowanie strategii unikania przez bilingwalne dorosłe osoby jąkające się z Libanu, autorki: Nadia Brejon-Teitler, Tala Haouili, Selma Saad Merouwe; Podejście Palin PCI $w$ terapii jąkania u dziecka trójjęzycznego - studium przypadku, autorki: Urszula Modrzyk, Edyta Saran-Pasoń), niepłynności mowy u dzieci (Wczesna interwencja w jąkaniu u dzieci - wyniki międzynarodowego sondażu diagnostycznego, autorzy: Joseph Agius, Aleksandra Boroń, Katarzyna Węsierska; Gry i techniki projekcyjne w terapii dzieci z zaburzeniami komunikacji (w tym z jąkaniem), autorki: Maria Faściszewska, Jagoda Tuchowska; Terapia grupowa dla dzieci z jąkaniem i ich rodziców - opis procesu, autorki: Justyna Solecka-Głodek, Joanna Szymczakowska; Terapia interakcyjna rodzic-dziecko Palin PCI - studium przypadku, autorka: Justyna Solecka-Głodek), narzędzi diagnostycznych (Behaviour Assessment Battery - normalizacja testu do badania dorosłych osób jąkających się, autorki: Marta Danielowska, Maria Faściszewska, Aleksandra Krawczyk, Jagoda Tuchowska, Martine Vanryckeghem, Katarzyna Węsierska), postaw otoczenia wobec jąkania się oraz ich przemian (Zmiana postaw względem jąkania wśród polskich nauczycieli i studentów, autorzy: Irena Polewczyk, 
Kenneth O. St. Louis, Katarzyna Węsierska), a także samopoczucia i jakości życia osób jąkających się (Stawać się swoim własnym terapeuta - rola autoterapii $w$ jąkaniu, autorki: Izabela Michta, Barbara Zuber; Poczucie zdrowienia $w$ diagnozie i terapii osób z zaburzeniami płynności mowy - na przykładzie STORI(J), autorka: Katarzyna Urbaniak-Głąb; Jakość życia dziecka jąkającego się - analiza przypadku w kontekście funkcjonowania psychospołecznego, autorki: Julia Dziukiewicz, Agata Sakwerda).

Następnie uczestnicy mogli wysłuchać dwóch wykładów mistrzowskich. Pierwszy z nich, zatytułowany Wsparcie osób jąkających się w procesie zmiany, wygłosiła Trudy Stewart. Badaczka przez blisko 40 lat pracowała z jąkającymi się dziećmi i dorosłymi w Wielkiej Brytanii, w wykładzie zaś poruszyła kwestie takie, jak terapia jąkania się oraz możliwości udzielenia wsparcia osobie nim dotkniętej podczas tego procesu. Ostatnim występującym w tej części konferencji był Mieczysław Chęciek, który zapoznał uczestników z dwoma podejściami w terapii jąkających się (młodzieży i dorosłych), kładąc nacisk na wady i zalety płynące z wykorzystania każdej z metod terapii. Podczas dyskusji słuchacze, chcąc jak najwięcej dowiedzieć się od mistrzów, zadawali pytania dotyczące wsparcia i terapii osób jąkających się.

Po mistrzowskich wystąpieniach odbyły się trzy sesje panelowe. W ich skład wchodziły cztery miniseminaria ( $w$ tym dwa anglojęzyczne), podczas których wystąpili: Jan Dezort (Ocena i podsumowanie doświadczeń w pracy z Palin Parent Rating Scales $w$ Czechach), Marlena Puchowska (Transkorowa afazja motoryczna a niepłynność mówienia), Aleksandra Krawczyk (Rozważania etyczne w badaniach i praktyce logopedycznej) oraz Justyna Solecka-Głodek (Umiejętności interpersonalne logopedy).

Niezwykle interesującą częścią konferencji był otwarty panel dyskusyjny zatytułowany Wehikut czasu: co chcielibyśmy powiedzieć naszym nauczycielom i logopedom o jąkaniu. Jego uczestnikami byli: Grzegorz Chmielewski, Lucyna Jankowska-Szafarska, Izabela Michta, Katarzyna Ploch oraz Agata Sakwerda, określani mianem „podwójnych ekspertów” w tej kwestii, ponieważ każdy z nich jest zarówno osobą jąkającą się, jak i zawodowym terapeutą, logopedą czy liderem grup samopomocowych dla osób jąkających się. Moderatorką dyskusji była Katarzyna Węsierska. Podczas panelu słuchacze poznali doświadczenie tychże osób $w$ zakresie trudności $w$ szkole, $w$ trakcie terapii, a także $w$ życiu codziennym. Uczestnicy odpowiadali na pytania zadawane przez prowadzącą, a następnie na liczne pytania publiczności. Tym sposobem zgromadzone audytorium mogło dowiedzieć się, co eksperci zrobiliby, mając możliwość cofnięcia się w czasie, z posiadaną obecnie wiedzą. Czy chcieliby, aby terapie, w których uczestniczyli, były prowadzone inaczej, czego byłoby w nich mniej lub więcej, jakie były ich doświadczenia szkolne, zwłaszcza związane z udzielaniem odpowiedzi ustnych czy relacjami w grupie rówieśniczej, co ułatwiało lub utrudniało komunikację $w$ tych relacjach. Sporo uwagi poświęcono także kontaktom z nauczycielami: uczestnicy zostali poproszeni o przytoczenie sytuacji, w których zachowania wychowawców okazywały się pomocne, oraz takich, w których - mimo ich dobrych intencji - wywoływały skutek odwrotny od zamierzonego. Najbardziej zaskoczyły odpowiedzi na pytanie zadane przez Tomasza Woźniaka. Przedstawiciel Uniwersytetu Marii Curie-Skłodowskiej zapytał o to, czy $w$ życiu osoby jąkającej się następuje moment, w którym podnosi ona głowę i staje się wojownikiem. Okazało się, że większość z uczestników panelu prawdziwą walkę o siebie podjęła dopiero $w$ dorosłości. 
Piątkowe obrady zakończyły się w kuluarach uroczystą kolacją, podczas której miało miejsce wręczenie Nagrody im. ks. Stanisława Wilczewskiego, przyznawanej osobom, instytucjom lub ruchom społecznym służącym idei promowania wiedzy o zaburzeniach płynności mowy, oraz przyznanie grantu im. prof. Gene’a Bruttena, przeznaczonego dla młodych osób działających na rzecz szerzenia wiedzy i wymiany doświadczeń w zakresie zaburzeń płynności mowy oraz dla logopedów zaangażowanych w badania nad tym zagadnieniem. Laureatką wspomnianej nagrody została Aldona Grzybowska, natomiast grant otrzymała Aleksandra Boroń.

Drugi dzień konferencji rozpoczęły kolejne wykłady mistrzowskie. Pierwszy z nich wygłosił Kurt Eggers, przedstawiając wyniki badań nad porównaniem funkcji wykonawczych, na przykład czasu reakcji na różne bodźce u dzieci z zaburzeniami płynności mowy oraz u dzieci bez zaburzeń. Następnie głos zabrał Benny Ravid i - dzięki odwołaniu się do własnych doświadczeń - przybliżył słuchaczom trudności, z którymi musi się mierzyć osoba jąkająca się. Barwnie opisał stany emocjonalne, jakie stają się jego udziałem podczas bloków, oraz wpływ niepłynności mowy na samoocenę i ogólne postrzeganie siebie, porównując te problemy do części góry lodowej ukrytej pod powierzchnią wody.

Po mistrzowskich wystąpieniach i dyskusji rozpoczęły się cztery sesje panelowe, podczas których odbyły się cztery miniseminaria prowadzone przez Dorotę Kamińską (Teoria ograniczeń i jej praktyczne zastosowania w terapii jąkania), Annę Szerszeńską (Aspekt dwujęzyczności w pracy z jąkającym się dzieckiem i jego rodzina), Łukasza Kowalczyka (Postawy i emocje wobec jąkania. Modyfikacja modelu góry lodowej Sheehana) oraz Lucynę Jankowską-Szafarską (Wzmacnianie samoakceptacji i poczucia sprawstwa $w$ terapii modyfikacji jąkania). Wygłoszonych zostało również sześć referatów, w tym: Mieczysława Chęćka i Edwina Bażańskiego (Objawy niepłynności mówienia u osób dorosłych oraz propozycje terapeutyczne z użyciem dominującego podejścia "mówić bardziej płynnie" - studia przypadków), Roberta Zielonki (Jakanie - objawy, metody oraz skuteczność terapii), Marii Mielnik (Przebieg początkowego etapu rehabilitacji zaburzenia płynności mowy u leworęcznej pacjentki $z$ afazja motoryczna powstała na skutek lewopółkulowego udaru niedokrwiennego), Urszuli Antończuk-Grab i Grzegorza Chmielewskiego (Wsparcie społeczne dla rodzin dzieci z niepłynnością $w$ mówieniu), Karoliny Jankiewicz i Grzegorza Chmielewskiego (Wiedza o jąkaniu wśród nauczycieli) oraz Aleksandry Krawczyk (Wyniki badań nad jąaniem i typowymi zaburzeniami płynności mowy u osób bilingwalnych, posługujących się językiem polskim i angielskim). Podczas czwartego panelu odbyły się warsztaty Trudy Stewart, dotyczące współpracy ze szkołą i nauczycielami dziecka jąkającego się, w czasie których w ramach burzy mózgów opracowywane zostały strategie postępowania logopedy na poszczególnych etapach edukacji. Warsztaty tłumaczono konsekutywnie na język polski. Po zakończeniu sesji panelowych i po przerwie obiadowej uczestnicy po raz drugi mieli okazję przyjrzeć się stworzonym posterom oraz porozmawiać z ich autorami.

Następnie odbyła się ostatnia seria wykładów mistrzowskich. Pierwszy z nich wygłosiła Mannon Spruit, poruszając temat giełkotu - zaburzenia płynności mowy wciąż znacznie słabiej znanego i rozpoznawanego niż jąkanie się. Jako ostatnia wystąpiła Katarzyna Węsierska, której wykład mistrzowski dotyczył udzielania wsparcia dorosłym osobom jąkającym się i korespondował z plakatami opracowanymi przez międzynarodowy zespół 
logopedów, dostępnymi w sześciu językach - polskim, angielskim, czeskim, słowackim, arabskim i francuskim.

Konferencja obejmowała wiele wydarzeń towarzyszących. W ramach kampanii społeczno-edukacyjnej Labirynty Komunikacji zorganizowano między innymi panel dyskusyjny pt. „Dialog bez barier”, podzielony na dwie części: etyczną oraz logopedyczną. Pierwszą z nich moderowała Agnieszka Skrzypczyk, a referaty wygłosili: ks. Antoni Bartoszek (Komunikacja z osobami niepełnosprawnymi intelektualnie, wystąpienie połączone z krótkim koncertem zespołu Ośrodka dla Niepełnosprawnych „Najświętsze Serce Jezusa” w Rudzie Śląskiej), ks. Grzegorz Polok (Korzenie rodzinne a zdolność do dialogu z samym soba i drugim człowiekiem), Ewa Porada (Komunikacja $w$ rodzinie. Inicjatywy duszpasterstwa rodzin Archidiecezji Katowickiej), Halina Koselska-Kubiak (Pozawerbalne doświadczanie, przeżywanie i wyrażanie duchowości). Po dyskusji i przerwie rozpoczęła się druga - logopedyczna - część spotkania, moderowana przez Iwonę Michalak-Widerę, podczas której wystąpili: Łucja Skrzypiec (Dziecko bawi się i uczy się mowy), Justyna Wojciechowska (Porozumienie - priorytet współczesności) oraz Benny Ravid (Co ludzie powinni wiedzieć o osobach jąkających się i o jąkaniu).

Ostatnimi z wydarzeń towarzyszących konferencji były warsztaty dla logopedów oraz osób jąkających się. Odbywały się one równolegle 2 września 2018 roku. Pierwsze $z$ nich, dotyczące behawioralno-poznawczych strategii interwencji terapeutycznej $w$ jąkaniu się, prowadził Kurt Eggers. Ekspert przybliżył uczestnikom metody interwencji $w$ jąkaniu się, uwzględniające korelacje pomiędzy czynnikami predysponującymi, wywołującymi i podtrzymującymi zaburzenia płynności mowy, tak by terapia była dostosowana do potrzeb klienta. Drugie z zajęć prowadzili Izabela Michta i Benny Ravid. Warsztaty skierowano do dorosłych osób jąkających się, a ich celem było doświadczenie (i obserwacja u siebie) tego zaburzenia z odmiennych perspektyw. Uczestnicy mieli możliwość wzięcia udziału w różnorodnych aktywnościach - od ćwiczeń inspirowanych psychodramą czy mindfulness po rozmowy przy okrągłym stole.

Trzecia edycja Międzynarodowej Konferencji Logopedycznej „Zaburzenia płynności mowy - teoria i praktyka" zakończyła się sukcesem. Dowodem tego są nie tylko licznie przybyli goście z Polski i z zagranicy, ale również szerokie grono odbiorców, którzy uczestniczyli w obradach $w$ trakcie dwóch dni konferencji. Duża liczba zainteresowanych potwierdza, że temat zaburzeń płynności mowy, diagnozy, badań oraz terapii jest istotną i wciąż aktualną częścią logopedii. 